\title{
The Applicability of Active-Participatory Methods
}

\author{
Nicoleta Ramona Ciobanu* \\ Assistant Professor, PhD, University of Oradea, Faculty of Humanistic and Social Sciences
}

\author{
*Corresponding Author: Nicoleta Ramona Ciobanu, Assistant Professor, PhD, University of Oradea, \\ Faculty of Humanistic and Social Sciences
}

\begin{abstract}
Active-participatory methods are an important factor in creating optimum conditions for a quality education that develops the skills and skills needed for a good pupil-student-teacher dialogue. These tools of work have become indispensable in recent times, because they rely not only on the cognitive skills of learning but also on the mental and emotional ones. Active-participatory methods can help increase school performance, can even be improved as a direct application to the class in an attractive and relaxing work environment for students. Developing certain capabilities involves causing certain types of intellectual processes. Through active-participatory methods, the didactic framework must be able to create situations where children are forced to use a vast array of processes and mental operations so that they have the opportunity to use the material taught to solve the given tasks.
\end{abstract}

Keywords: Active-Participatory; Methods; Education; Learning; Modern; Applicability

\section{INTRODUCTION:}

Active-participatory methods emphasize operational knowledge, learning by action; bring students into direct contact with real life situations.

Active-participatory methods are procedures that start from the idea that learning is a personal activity that cannot be replaced by anything, and the learner is considered to be the manager of his / her own learning, of the whole learning process. This becomes a unique and different activity from one person to another, being determined by the personal history of the subject, by the environment in which it originates, and by the social relationships it develops. Active-participatory methods involve activism, intrinsic curiosity, the desire to observe, explain, explore, discover. Active and participatory are those methods that mobilize the student's energies that help him concentrate his attention, stimulate his curiosity. Active-participatory methods emphasize operational knowledge, learning by action; bring students into direct contact with real life situations. These methods are educational, for example: independent reading, heuristic dialogue, exploration and discovery learning, collective discussions, etc. Therefore, learning is a personal activity that belongs to the individual; is a personal act that involves the student altogether. These methods focus exclusively on the child and are decisive in shaping the personality.

Looking at the child as a subject of learning, active-participatory methods consider that the educational and formative effects of education are proportional to the level of engagement and participation in the learning activity; that in the learning situation he is involved in calling for intellectual skills, which are based on different learning abilities; that each of these capacities can be analyzed from the point of view of the mental processes involved. Developing certain capabilities involves causing certain types of intellectual processes. These are different resources for each child to engage personally in the act of learning.

There are cases in which some children call more memory, memory and understanding operations; others to think (the ability to put and solve problems). In cases that they use more thinking, it develops either convergent thinking operations involving the search for and finding a simple and correct answer; or divergent thought processes that lead to the emergence of possible answers, to an 
open-ended situation; or to an appreciative thinking that leads to certain judgments based on implicit or explicit criteria; therefore, some appeal to the creative skills that would imply the ability to develop ideas; and others to critical thinking based on the ability to analyze, interpret and explore. Piaget shows that the purpose of the new methods is to create conditions that foster the development and involvement of these capacities, processes and operations. When learning situations are well organized, children get involved with different capacities and have the chance to develop them. Through active-participatory methods, the didactic framework must be able to create situations where children are forced to use a vast array of processes and mental operations so that they have the opportunity to use the material taught to solve the given tasks. We are talking about operations such as: observing, identifying, comparing, opposing, classifying, categorizing, organizing, calculating, analyzing and synthesizing, verifying, explaining the causes, apprehending the essentials, correcting, establishing functional relationships, abstracting and generalizing, critical judgment, anticipation, image sharpening, forming one's own opinion, extracting information, communicating, etc. Activeparticipatory methods include all those methods that trigger an active learning state, a learning that is based on one's own activity. These are the methods that lead to the active forms of learning, explorative learning, problem-solving, learning by doing, creative learning; are methods that involve children in carrying out independent study, work with books, research learning, practical things, creative exercises, etc.

Active learning engages creative-creative capacities, thinking and imagination, and uses the mental and cognitive structures that the preschool has and is used to produce the new learning. Modern education is based on an action-oriented methodology. From this point of view, active-participatory methods are based on the idea of the operative constructivism of learning "Engaging in a constructive effort of thinking, knowledge, or pragmatics is likely to take the pupil out of the crunch where he is eventually held by education centred on a network of fixed verbal expressions, such as statements, definitions, invariable procedures, rules rigid, etc. and to reserve an active role in interacting with the material to be studied (content-stimulus)'. [1] To the extent that the methods on which we base manage to mobilize the psychological and physical effort that comes from within the learner, the interests and desires of knowledge, initiative, intrinsic motivation (success and overcoming difficulties), then they really have the right to and claim ownership of what they usually do, calling themselves active-participatory methods. This category includes both heuristic and practice-based methods.

Teaching should be seen as a way of stimulating and developing intellectual capabilities, but also of the processes and operations underlying these capacities. Starting from this premise, we can say that the internal logic of the discipline does not develop the logic of the child's overall thinking. Compared to the traditional methodology, for which the preschool remains more a reproducer of the information presented by the teacher, the active-participatory methods make him an active participant in the learning process, ready to acquire knowledge through his own effort, engaging thinking and mobilizing all the functions intellectual in relation to the given learning task.

Working with modem methods, the teacher plays an essential role. He must put all his knowledge and his skill into play, not simply to convey knowledge to be learned mechanically, but to instil in his children the desire to acquire them through themselves the most active and intensive study. The role of the teacher is to organize learning, to support the effort of children, and not to take over all or part of this endeavour. It is understood that active-participatory methods are more difficult to apply in practice and therefore require more careful and differentiated work.

Jean Piaget (1972) emphasizes that success depends on pedagogical methods and even the best planning is unsustainable if it does not involve a methodological renewal with the technological one (apud Ioan Cerghit, 2006). However, progressive but isolated educational changes in the school education system only cause a general imbalance. Therefore the whole educational-educational process remains open to more effective training methods. The fact that the renewal of the methodology is a continuous process does not mean that it knows only one and only one orientation, namely the one-way orientation. On the contrary, it is based on multifunctional reflection with sufficient openings to the quantitative and qualitative aspects of didactic activity.

In this regard, Ioan Cerghit (2006) argues that there are two fundamental orientations, namely:

- A quantitative one referring to the tendency to multiply and diversify the methods, 
- The second qualitative, which refers to the renewal and modernization of the methods, but also to their degree of opening.

The quantitative orientation tends to uniformize learning and teaching, to mechanically extend the application of some and the same methods. It should be emphasized that there is a wide variety of ways in which children and young people learn in school but also outside school. From this point of view, no learning situation resembles one another because learning is a personal act that belongs to each individual. Every child, adolescent or young person is unique in its own way, so each activity / learning action is unique and differs from child to child. No method is the only and only effective way in which a learning situation can take place. No method can be given absolute value; it cannot be as effective for all children.If a method is considered good for some students it is not necessarily good for others. Each method is only a possibility among other possibilities of teaching / learning; each method represents a new attempt to find an effective learning path.

\section{CONCLusions}

Diversified application of methods makes it easy to move from one activity to another, from cognitive level to another. Variety offers the individual multiple chances, putting him in the position to achieve the maximum performance he can reach. Diversity prevents and eliminates monotony and boredom, fatigue and the risks of a decrease in performance in the theoretical and practical training, makes individual learning more attractive, requires greater responsibility from both the teacher and the children. The variety of methods also helps to diversify teacher-child, child-child, team-children, children-collectively relationships and multiply the roles they can assume in the education process.

The variety of methods and procedures used does not only help the child, it also greatly enriches the teacher's didactic experience, offers a wider range of alternatives and possible choices, the possibility of making the most appropriate decision, adopting the optimal solution for a situation or another for studying. Developments in qualitative resonance refer to general methodological concepts or to general approaches to didactic procedures (this view is dealt with in active-participatory methods).

[1] Cerghit, L, Metode de învăţământ. Iaşi, (2006).

\section{REFERENCES}

[2] Cucoş, C., Pedagogie ediţia a II- a revăzută şi adăugită. Iaşi, Polirom Publishing House (2006)

[3] Nicola, I., Cercetarea psihopedagogică, Bucharest, EDP Publishing House, (1993),

[4] Sacară, L., Damian, I., Macarie, G., Voichiţă, A., Psihopedagogie în sinteze. Bucharest, EduSoft Publishing House (2006).

[5] Şchiopu, U. Psihologia vârstelor, Bucharest, EDP Publishing House (1970).

\section{AUTHOR's BIOGRAPHY}

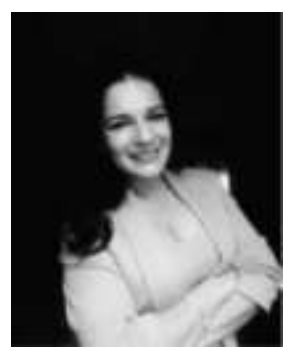

Nicoleta Ramona Ciobanu, I have 37 years old and from 2014 I have started my work as an assistant professor PhD at the University of Oradea, at the Faculty of Humanistic and Social Sciences. I love my job and that is the reason for which I dedicate my time to work with my students on different projects related to the field of Education. For this reason the student elect me as a Bologna teacher in 2016 (there is a community in Romania of the best teachers in the country based on students election), and for that I am so grateful and proud. I successfully combined my studies with work and other commitments showing myself to be self-motivated, organized and capable of working under pressure.

Citation: Nicoleta Ramona Ciobanu "The Applicability of Active-Participatory Methods" International Journal of Humanities Social Sciences and Education (IJHSSE), vol 4, no. 11, 2017, pp. 167-169. doi:http://dx.doi.org/10.20431/2349-0381.0411019.

Copyright: (C) 2017 Authors. This is an open-access article distributed under the terms of the Creative Commons Attribution License, which permits unrestricted use, distribution, and reproduction in any medium, provided the original author and source are credited. 